жатыр. Мысалы, түсті білдіретін ақ сын есімі кейін келе «адал», «тағам аты» (сүт тағамдары), «ақиқат, шындық» деген мағыналарды қосып алған.

Лексика-семантикалық тәсіл арқылы заттану процесі арқылы зат есім сөзге айналған сөздер тілімізде өте көп. Мысалы: бүлдірген, аварzан, айтыс, қоршау, ақ, жетісі, қырққы, жаратқ̧ан, туысқ̧ан т.б.

Септік жалғауларының көнеруі арқылы да, яғни лексика-семантикалық тәсілдің қатысуымен үстеу сөздер де жасалған. Мысалы, текке, бірден, зорга, бекерге, кейде, шетінен, шынымен, қапыда, етпетінен, шалққасынан т.б.

Лексика-семантикалық тәсіл арқылы тілімізде көптеген термин сөздер жасалған. Мысалы, тіл білімінің терминдері болып табылатын екпін, буын, мавына, үстеу, жұрнақ т.б. сөздер о баста жалпы көпшілікке арналған сөз болып, біртіндеп терминдік мағынаға ие болған. Бұл ғылымның басқа салаларына да тән құбылыс. Мысалы, теңеу, суреттеу, әнціме әдебиет терминдері, бұрыш, көбейту, қосу, алу сияқтылар математикалық терминдер сөзжасамның осы лексика-семантикалық тәсілі арқылы жаңа мағынаға көшкен.

Сонымен, келтірілген мысалдар лексика-семантикалық тәсілдің сөздік құрамды байытуда өзіндік орны барын білдіреді. Ал сөзжасам тәсілдері арқылы жасалған туынды сөздердің барлығы сөзжасам процесінің нәтижесі болып табылады.

\title{
ӘДЕБИЕТТЕР ТІЗІМІ:
}

[1] Қазақ тілінің сөзжасам жүйесі. - Алматы: Ғылым, 1989. - 368 б.

[2] Қазақ грамматикасы. - Астана, 2002. - 784 б.

[3] Оралбаева Н. Қазақ тілінің сөзжасамы. - Алматы, 2002. - 189 б.

[4] Салқынбай А. Тарихи сөзжасам. Семантикалық аспект. Алматы, Қазақ университеті, 1999. - 309 б.

[5] Қасым Б. Қазақ тіліндегі заттың күрделі атауларының теориялық негіздері: филол. ғыл. докт. ... автореф. - Алматы, 2002. - 50 б. 456 б

[6] Қайдаров Ә. Қазақ тіліндегі қос сөздер: зерттеу және сөздік. - Алматы, 2013.

[7] Оразов М. Қазақ тілінің семантикасы. - Алматы: Рауан, 1991. -216 б.

МРНТИ: 16.21 .33

\section{Б. Момынова ${ }^{1}$, Y. Әнесова}

1'А.Байтұрсынұлы атындағы Тіл білімі институтының бас ғылыми қызметкері филология ғылымдарының докторы, профессор

Грамматика бөлімінің меңгерушісі

²әл-Фараби ат. ҚазҰУ оқытушысы, $\mathrm{PhD}$ докторы

ҚАЗАҚ ЭТНОМӘДЕНИ ЛЕКСИКАСЫНЫН ӨТКЕНІ МЕН БҮГІНІ

ТІЛШІҒАЛЫМДАР ЗЕРТТЕУЛЕРІНДЕ

(Е. Жанпейісов пен Ж. Манкеева зерттеулері негізінде)

Аннотация. Мақалада қазақ этнолингвистиканың бір кезеңі, осы кезеңде 
жазылған еңбектерге шолу жасалады. Қазақ этнолингвистикасын дамытудағы профессор Е.Жанпейісовтің ғылыми еңбектері туралы сөз болады. Соның ішінде оның материалдық лексиканы жүйелеген «Қазақ ескіліктері» монографиясы туралы айтылады. Кейбір лексикалық бірліктер талданады. Мақалада профессор Ж.Манкееваның соңғы жылдары жазылған еңбегі де этнолингвистика саласына қосылған үлес ретінде қарастырылып, тілдік бірліктердің семантикасын, этномәдени маңызын жан-жақты ашып көрсеткені айтылады.

Тірек сөздер: этнолингвистика, этнос, материалдық лексика, белгі, мәдениет феномені, идиоэтникалық семантика, символ, семиотика, концептуалдану.

\author{
Б. Момынова ${ }^{1}$, У. Анесова² \\ ${ }^{1}$ главный научный сотрудник, зав. отделом грамматики \\ Института языкознания имени А. Байтурсынова \\ доктор филологических наук, профессор \\ Алматы, Казахстан \\ ${ }^{2}$ преподаватель КазНУ им. аль-Фараби, докторант $\mathrm{PhD}$ \\ Алматы, Казахстан
}

\title{
ПРОШЛОЕ И БУДУЩЕЕ КАЗАХСКОЙ ЭТНОЛИНГВИСТИКИ В ИССЛЕДОВАНИЯХ КАЗАХСКИХ ЭТНОЛИНГВИСТОВ (на основе исследований Е.Жанпеисова и Ж.Манкеевой)
}

Аннотация: The article examines one of the periods of development of ethnolinguistics, as well as scientific works written during this period. In particular, we are talking about the role and contribution of Professor E. Zhanpeisov in the study of Kazakh ethnolinguistics. The article analyzes the scientific works of the scientist, including his latest monograph „Kazakh eskilikteri». Some lexical units are covered in detail. The article also examines the works of Professor Zh. Mankeeva in recent years from the point of view of their contribution to the field of ethnolinguistics, the study of the semantics of linguistic units, their ethnocultural significance.

Ключевые слова: этнолингвистика, этнос, материальная лексика, знак, феномен культуры, идиоэтническая семантика, семиотика, концептуализация.

\section{B. Momynova ${ }^{1}$, U. Anesova ${ }^{2}$}

${ }^{1}$ Chief researcher of the Institute of Linguistics named after A. Baitursynov,

Doctor of philological sciences, professor

Head of the Grammar Department

Almaty, Kazakhstan

${ }^{2}$ Lecturer of Al-Farabi Kazakh National University, PhD

PAST AND FUTURE OF KAZAKH ETHNOLINGUISTICS IN THE RESEARCH OF KAZAKH ETHNOLINGUISTS

(research by E. Zhanpeisov and Zh. Mankeeva) 
Abstract: The article deals with a specific period of ethnolinguistics, as well as the role and contribution of Professor Zhanpeisov E. to the research of Kazakh ethnolinguistics, scientific works of the scientist, including the last monograph of the scientist entitled "Kazakh eskilikteri». Some lexical units are subject to linguistic analysis. The article examines the work of Professor Zh. Mankeeva's recent contribution to the field of ethnolinguistics, revealing the semantics of linguistic units, ethnocultural meaning.

Key words: ethnolinguistics, ethnos, material vocabulary, sign, cultural phenomenon, idioethnic semantics, semiotics, conceptualization.

Этномддени лексика дегеніміз не? Этномддени лексикага, біріншіден, белгілі бір этнос тіриілік кешетін аймаққа тән табиват құбылыстарының атаулары, екіншіден, материалдық лексика, үшіншіден, рухани лексика элементтері жатады. Материалдықлексиканың бір бөлігі тұрмылтылқлексикадан тұрады. Ал тұрмыстық қ лексикава талдау жүргізу дегеніміз жеке бір ұлттың, тұтасымен алванда адамзат қауымының даму үрдісіне және көрші жатқан елдердің бір-біріне, тіпті тымм альставы елдің белгілі бір ұлт пен халықтылы, этностың тұрмысс-тіршілігіне жанасатын тұстарын, сол арқылы тіліне тигізген әсерін анықтаува мүмкіндік алумен бірдей.

2000-жыллдардың басы. Ғылым ордасында ҚР ЖОО-лары ассочичачиясының оқулықтар мен оқу құралдарының сапасына арналван жсиыны өтіп, сован қатыссува шақырылдық. Осы жинальста үш автордың (М.Томанов, Б.Манасбаев, Е.Жанпейісов) бірлестігімен ертеректе жарық көрген «Қазақ тілінің стилистикасы» окульгы марапатқа ие болван еді. Қайран Ербол авамыздың үн-түнсіз қуанышиьның куасы болдық. Үш автордың көзіндей жалвыз өзі марапатты алды. Бүгінгі сөз филология гылылмарының докторы Ербол ага Жанпейісовке багышталады. Егер арамызда болса, осы жылы 90-ва толган мерейлі жасын атап өтер еді.

Бүгінгімақаладасөз болатынбелдівалымдарыныңзерттеулері А.Байтұрсынұльы атындавы Тіл білімі институтында орындалван. Осы выльым ордасы - қазақ тіл вылымның қ̧ара шаңыыравы әрі іргелі теориялықз зерттеулер дүниеге келетін қ̧асиетті мекені.

$* * *$

Қазақ этнолингвистикасының қалыптасуына, дамуына тоқталуды мақсат етіп, оны мақала жүгіне айналдыру көзделген жоқ. Осы саланың ел таныған айтулы мамандарының кейбір еңбектері туралы әріптес ретінде, ағадан жылы сөз етіп, жігерін жаныған қарындас ретінде ғана пікір білдіру ойда болғанын ескерте кету керек. Сондықтан саланың тарихы деп, өткені деп толғанбай, тікелей екі ғалымның еңбектеріне тоқталамыз.

Ербол Жанпейісов біз көрген аға буын өкілдерінің ішіндегі өз жұмысын артық сөзсіз, ақырын ғана тындырып жүретін ғалым ретінде есімізде қалды. Ғалымның М.Әуезовтің «Абай жолы» романындағы этнолигвистикалық бірліктерді жинақтап, жүйелеп, мағыналық және құрылымдық талдау жасаған еңбегінің өзі ірі дүние еді. Кейіннен өмірінің соңына қарай жазған «Қазақ ескіліктері» (Алматы, 2018) деген этнолингвистикалықмонографиясыда күрделілігімен, болжамдарыныңтереңдігімен, материалдарының молдығымен, тек тарихи-салыстырмалы емес, тарихи-салғастырмалы тәсілді кең қолдануымен, ғылыми аппаратының жан-жақтылығымен айрықша 
болып шықты. Бұл еңбек бұрын-соңды жазылған этнолингвистикалық еңбектердегі ойды жалғастырып қоймай одан әрі тереңдете алған, алдыңғы еңбектерден көп ілгерілеген, халыққа керекті, танымал еңбек болды. Өйткені әр халық өзіне тән образдар, ұғымдар мен символдарды жинақтап, мәдениеттің ұлттық формасын жасайды. Ұлттық түрді құрауға материалдық лексика элементтері қатысады. Былай қарағанда заттық лексика элементтері - жансыз фактілер, бірақ ғасырлар мен ғасырлардың мәдени диалогына қатысушылар үшін көп жағдайды хабарлайды, көп мәлімет жеткізеді. Кез келген мәдениетте салт-дәстүр, әдет-ғұрып, амандасу мен қоштасу, тұрмыстық заттар мен бұйымдар (үй, үй жиһазы, киім, дәм-тұз), адамның сыртқы бейнесі, оның мінезқұлқы - бәрі де мәдени-танымдық функция атқарады, ақпарат жеткізеді. Тұтасымен алғанда мәдениеттің көптеген құбылыстары қосқырлы: а) олар өздерінің негізгі утилитарлық функциясын атқарады, б) белгінің орнына жүреді. Осы екі қызметті қатар алып жүретін материалдық лексика мәдениетті құрайтын ірі құрамдас бөлік және лексикалық тақырыптық топ құрайтын сөздерге жатады. Сондықтан материалдық лексика кез келген ұлттың дамуын, эволюциясын көрсететін тілдік айғақтар саналып, халық тарихымен сабақтастықта зерттеледі. Айталық, киім-кешек атаулары - тарихиэтнографиялық қайнаркөз әрі тілдегі сандаған бірліктердің қалыптасуына негіз бірліктер, ұлт мәдениетінің үлкен бір бөлімі. Е.Жанпейісовтің айтуынша: «Мәдениеттің нақты этникалық табиғатын оның осы біртұтас семиотикалық жүйе болып табылатын архаикалық қалпын зерттеу арқылы ғана тереңірек танып білуге болады. Мәдениетті жеке заттар, құбылыстар, оқиғалар түріндегі таңбалар жиынтығы ретінде алып қарастыру керек» [1]. Расында да мәдениет - ең алдымен күрделі семиотикалық жүйе, оның қызметі-сана қалыптастыру, негізгі ерекшелігі-жинақтап сақтау.Ғалым Е.Жанпейісовтің монографиясында жеке заттар, құбылыстар мен оқиғалар түріндегі таңбалар атау, символ, қимыл-қозғалыс актілері ретінде семантикаланады. Мәдени заттардың кейбірі символданады. Қоршаған ортаны, тіпті дүниедегі барлық нәрсені символдар арқылы кескіндеуге болады. Символдар - таным мен қарым-қатынас үдерісінде басты да, көмекші де мағынасы бар таңба түрі. Символдардың адамзат қоғамындағы, адам өміріндегі рөлі зор, бірақ символды басты және дүниені танудың жеке-дара жалғыз формасы деп қарауға болмайды. Адамдарға әркелкі әсер ететін, сондықтан да белгілі бір сезімдермен, жағдайлармен, қатынастармен байланыста болатын әртүрлі заттар мен олардың ерекшеліктері де символ ретінде қолданыла береді. Символдың коммуникативтік, атауыштық, сипаттамалық, жалпылауыштық, абстрактілі қызметтері бар. Соған қоса, символ таңбаға қарағанда, танымдық қызметімен, мазмұнымен ерекшеленеді. Мәселен, таңба көбінесе шартты немесе бірқырлы болуы мүмкін, ал символ концептуалдану үдерісінің нәтижесі және кез келген тілдік бірлік тәрізді кумулятивтіқызметіарқылыхалықтыңэстетикалықтаным-түсініктерін,шаруашылық кәсібін, мінез-құлық, ырым-наным, салт-дәстүрін танытады. Ал «символдың тілдегі көрінісі мен адам өміріндегі рөлі және қызметі, мәдениетке, этностың дүниетанымы мен өмір сүру принциптеріне тигізетін ықпалы нақты тілдік материалдар, тілдік фактілермен дәйектелетіндіктен, символдар мәдениеттің көрсеткішіне жатады». Ал сөз символ болу үшін белгілі бір мәтінде, көбінесе мәдени мәтінде қолдану керек. Е.Жанпейісов өз еңбегінде осындай бірліктерді жинақтап, ала білген. Ал мәдениет феноменінің ғылымда жалпы көп аспектілі және өте көп тармақты проблемаға жатуы осындай себептерден келіп шығады. Осыған байланысты оны зерттеудің түрлі жолдары қалыптасқан. Осыны терең түсінген Е.Жанпейісовтің атап өткен соңғы 
монографиясы жаңа бағыттағы өзгеше ізденістің жемісі деуге болады. Ғалым алдымен тірнек өнерді жеке бөліп алады да, оған киім-кешек үлгілерін, үй мүліктерін, баспана түрлерін, төрт-түліктен өндіретін бұйымдарды, азық-түлік өнімдерін немесе заттық мәдениетті жатқызады (бұларды ғылымда культурологтар, этнографтар қарастырады); әдет-ғұрыптық ишара көріністері мен символдық түрлі рәсімдік актілер жиынтығы рухани мәдениетті, яғни көрнек өнерді құрайды деп жеке бөліп тастайды. Ал бұлардың тілдік көріністері этнолингвистиканың зерттеу объектісіне жататыны шындық және олар заттық мәдениет лексикасын құрайды [1]. Бірақ ғалымның айтуынша: «аталмыш заттық-рухани мәдениет, яғни тірнек-көрнекөнер дихотомия$\boldsymbol{c b}$ көбінесе берірек дәуірге қаратылып айтылады. Берірек дәуірге қаратылып айтылатыны архаикалық мәдениет бұлай мүшеленбейді. Мүшеленбейтіні: ол - біртұтас семиотикалық жүйе». Міне, зерттеуші осы семиотикалық жүйені барынша «аралап көрген». Заттық мәдениет лексикасының идиоэтникалық ерекшеліктерін айқындауды бүгінге жеткен ескілікті льпп -киім түрлерінің «әр тарап тілдік көріністерін, олардың атаулар жүйесін қарастырудан бастап көрейік» дейді сөз басында ғалым. Ғалым зерттеуді бас киім атауларынан бастайды. Бас киімге байланысты атауларды түгендеуді фольклор, жыраулар поэзиясынан, көп жанрлы жазба әдебиет үлгілерінен, басқа да дереккөздерден жинастырған. Ең бастысы қазақ бас киімінің элементтерінің, сегменттерінің өзге ұлт өкілдерінің киімдеріндегі сегменттермен байланысын ашып бере алған. Сөйтіп барып киім атауларының идиоэтникалық семантикасын ашуда бұрыннан бар жолға түспей, одан түбегейлі бас та тартпай, жаңа тәсілдерді пайдаланған. Мысалы, сәукеле сөзінің ұлттық танымдық семантикасына бару үшін ғалым айтарлықтай көп сөздің фонетикалық өзгерістерін көрсетеді, семантикалық дамуына тоқталады, сөздердің арасындағы мағынадан, тұлғасынан тарихи сабақтастықты іздейді, сөйтіп барып, этимологиялық, идиоэтникалық семантикалық болжам арқылы бір тоқтамға келіп, тілдік фактімен тиянақталған дәлелін айтады. Сәукеленің идиоэтникалық семантикасын ашу үшін мына сөздердің даму эволюциясын көрсетіп, сәукеленің таңбалық сипатын ашуда пайдаланады: жалбавай, далбавай, телпегей, бүркей, жабасалма, қайырма, жапетер, қарқара, бергек, малақай, далбай, жалбай, желпей, төбетей, төбебөрік, желбегей, кама, жаулық, жұмыршақ, кәләпүш, күләпара, башлық, желек, тылмақ, мильқ, тақия, қалпақ, тәж, телпек, пәрәнжі, паранжы, шалма, қатырма, құлақшын, саль, сал, шәлі, сәлде, сұлама, жепен, зере, күндік, кепе, кепеш, кеп, шарқат, баутақ, кимешек, шаршы, желек, шылауыш, тебегей, бөкебай, бөрік, топь, топпа, дульга, жыға, қырпу, бүркеншік, келе, күлә, сәукеле. Дыбыстық варианттарымен қоса алғанда «алпыстан асатын мол тілдік материалды» пайдаланып, сәукеле сөзін талдайды. Аталған сөздер - бас киімге ғана қатысты сараланғандары. Ғылыми еңбектерде соңғы кездерде осындай жиынтық мәліметтерді, ғылымдар тоғысынан жиналған материалдарды пайдаланып зерттеу жүргізу өрістеп келеді. Ғылымдағы осы қозғалыстың тиімді жақтары мол. Осы бағытты ұстана жазылған ғалым монографиясы жөні бөлек еңбек болып шыққан. Неге осыған дейінгі материалдық лексикалық, этнолингистикалық зерттеулерден жөні бөлек еңбек? Айталық, ғалым бас киімді тек киім ретінде ғана емес, «бас киім түрлері дененің тек сырт жамылғысы ғана емес, сонымен қоса оның, яғни дененің жалғасы, тұлғаның өзіндік «экстериоризациясы» деп таниды. Шынында да, «киім үлгілерінің жалпы қай-қайсысының да адам денесінің белгілі бір бөлігін жауып тұруы - оның таза сырт жамылғы ретіндегі қызметі ғана. Ал оны (киімді) дененің жалғасы, тұлғаның өзіндік 
экстериоризациясы деп білу психологияда белгілі бір процесс нәтижесінде адамның ішкі психикалық өмірінің ерекше бір таңбалық құралы, нақты бір киім кию, шаш қою сияқты түрде вербалдануы» деп түсіндіреді. Семантикалық қосполюстілікпен байланысты қарастыра келіп, жеке адамның, тұлғаның экстериоризаииясы дегеніміз индивидтің ішкі психикалық дүниесінің белгілі бір шаш қою, киім киісі түрінде таңбалануы, көріністенуі деп біледі. Яғни бас киім тек киім емес, мағынасы әлдеқайда терең, материалдық семиотикасы аса жоғары, таңбалық қасиеті басым материалдық құндылыққа жатқызылады. Еңбектеталданған тілдік бірліктердің бәрінің де таңбалық қасиеті қарастырылған, нәтижесінде аталған еңбек түрлі ғылымдар тоғысынан, синтезінен туындаған ерекше еңбек болып шыққан. Мысалы, сәукеле туралы мәліметтермен танысу барысында 100 жылқының, тіпті 500 жылқының құнына бағаланған сәукелелер болғанын, олардың музейлерде сақталғанын келтірген ғалым сәукеленің бөліктерін танытатын құндыlз, шұва, ақ киіз, сусар, бұлвын, алтын, күміс, маржан, ақық, мәрмәр, гауһар тізбектері, шоқ үкі, оқаланван лента, таналар т.б. тілдік бірліктерді тек атап қоюмен шектелмеген. Келтірілген әрбір сөздің семантикалық, ділдік, танымдық дамуын өзге киімдерде кездесу себептерімен байланыстыра отырып, кешенді талдау жүргізеді, материалды жүйелей келе белгілі бір тұжырымға келеді: сәукеле көшпелілер үшін ғажайып өнер туындысы болған, өнер туындысы екені тілдегі қолданыстардан көрінеді, мысалы: «Сәукеле алтын шашақ березелі, Күмістен күмбез құққан керегелі. Өзінің ауырльгы сегіз батпан, Төбесі төрт қапсырма кебежелі (Н.Ахметбеков); Төсек алдында жаңа түскен жас келіншек. Сәукелесі басында, қайын сіңлісі қасында. Ұзындығы кез сәукеле, етегінен төгілген маржандар, алтын, күміс жарқыраван теңзелер, қатар-құатар ою сальп тізген меруерттер қызыылды-жсасылды больли, алыстан қараған кісінің көзіне шағылысып, таңырқарлық [болып] тамаша көрінеді (А.Асылбеков. Әдебиет кеші// «Қазақ» газеті); Жарас-ау мына сәнді көрмейсің бе? Сыбага сәукелеге бермейсің бе? (М.Әуезов); Қолымда сақинам бар бармақ-бармақ, Сәукеле басқа түссе ауыр салмақ (фольклор); Қапталь сәукеле тас құлын жайлау (Ә.Найманбаев); Әшекейлі товыз қатар сәукеле (Х.Арғынбаев). Мысалдарды оқып отырып, кебежелінің, товыз қатардың, сегіз батпан ауырльқтың, керегелі күмбездің сәукелеге не қатысы бар деген ой келеді. Ғалым бұлардың бәрінің де байланысы барын деректерді сөйлету арқылы бұлжытпай дәлелдей алған: «Жоғарыда Н.Ахметбековтен келтірілген Сәукеле алтын шашақ березелі деген өлең жолындағы березелі-туынды сын есім, түбірі березе> n. مزوريف (транскрипцияласақ, пируза фируза болып шығады - Е.Ж.) бирюза (камень) [БСл I: 325]. Парсы тілінде «асыл тас» мағынасын білдіретін бұл пируза//фируза есімі қазақ тілінде березе болып қалыптасқан. Ол сондай-ақ перезе, перуза түрінде де айтылады (Р.Н.Шойбековтен). Тіліміздегі Перуза, Фариза, Мариза антропонимдері осы пируза//фируза парсизмінің негізінде жасалған» дейді. Міне, бір сәукеленің семантикасын ашу барысында қаншама тілдік бірліктердің этимологиясына қозғау салынған. Алдында айтылған экстериоризациясының мәнін былайша аша түседі: «Еңбектерде ескілікті заттық мәдениет бұйымдарының әдетте әрі жай бір нәрсе, әрі таңба, символ ретінде тұтынылатыны жиі айтылады. Қай халықта да тек бір ғана тұрақты жоғары семиотикалы статусқа ие нәрселер де болады, ... оларға маскалар, амулеттер, әшекейлер жатады және бұлардың заттан гөрі таңбалық қасиеті жоғары», солай болу себебіне қарай таңбалық, семиотикалық қасиеттеріне тоқталып, осы бағытта ізденуді мақсат еткен. 
Еңбекте бірнеше атаулар талданады. Соның бірі - жүзік. Жүзік сөзінің түрік тілдеріндегі жазба ескерткіштерінде, өзге де түрлі дереккөздерінде кездесетін фонетикалық варианттарының ең толық тізбесін Л.С.Левитскаяның этимологиялық зерттеулерінен табуға болатыны айтылған. Е.Жанпейісов жүзік сөзі жоғарыда келтірілген түрлі лексикографиялық еңбектерде көбіне-көп сәндік бұйым, әшекей заттар атауы ретінде сипатталғанын, бірақ сәндік сипаты уақыт өте келе кейін пайда болғанын, рухани мәдениеттегі әуелгі бастау ұғымы бұдан басқарақ деп ойлайтынын дәлелдеген. Жүзік палеолитте сүйектен, неолитте тастан, қола дәуірінде металдан жасалған. Асыл тастардан көз қондырылғанын - жүзік, тасы жоқ тек алтын, күмістің өзінен ғана көз шығарылғанын - сақина, көзі жоқ шығыр түріндегісін - балдақ деп атайтынын, ал сырғаның да шығыршық сырва дөңгелек сырға болатынын келтіруі - таныс мәліметтерді сөйлетуі. Бірақ шумерлік деректерден тапқан: «Женитьба у шумеров считалась делом весьма обременительным. Они определили свое отношение к браку следующим образом: Кто не содержал жену или ребенка, тот не носил кольца в ноздрях, мужьям в шумере, как видно, приходилось порой несладко» (Семюэл Н.Крамер) сынды пікірлерді тауып алуы, ойландырады. Ғалымның бұл деректі жай келтірмегені мына сөзінен байқалады: «Біздің жобалауымызша: шығыршық түріндегі жүзік сияқты шығыршық түріндегі сырға да солай шу бастан таңба (символ) ретінде қолданылған. Өйткені «кольцо»ның заттылығынан гөрі таңбалылығы басым сияқты көрінеді». Қазақ өмірінен алынған мынадай дерек ғалымның пікірін тереңдете түседі: «Тоқбаланың өз әкесі Теңізбай, ұлы атасы Бектемір екеуі де айран ішерлігі мол дөңгелек дәулетті адамдар болыпты. Сүйікті немересін жат елге ұзатарда жасауын толық қылып, мінген атының алдыңды екі аягына күміс білезік салғызыпты. Немересінің мұрын кеңсірігіне қыстатын салпыншақ алтын сырzасымен қоса ұзатылыпты. Ертеде қазақтың кейбір руларында осындай салт ұстанған. Өзбекстанның Сұрхан Дария (Термез) облысында мұндай салт әлі күнге бар. Түрікмендер мен өзбектер ондай сырғаны «арабек» деп атайды. Ал қазақтар алтыннан соғылғанына байланысты зер сөзінен туындатып зере деп атаған тәрізді. Тоқбала ұзатылып барған тобықты елінде мұрынвасырва mazy салты бұрыннан болмаған ба, немесе ұмытыла бастаған кезі ме, әйтеуір бөтен жасау-жабдықпен түскен жас келінді мұрын сырғасына қарап Зере атандырыпты. Шежіреші Рахымбековтің түсіндіруі осылай» деген Қ.Алтынбаев дерегін келтіреді. Зере - шығыршық түріндегі мұрын сырғасы. Қазақтар - оны зере, зейір, әребек, арабек, қарақалпақтар - арабек, өзбектер-аравак, латива, ал түрікмендер-ысырzа деп түрліше атайды. Қазақтарда ертеде малдың мұрнына салынатын шығыршық та осылай зере деп аталған көрінеді. Ал бұның жаңада ғана шаңырақ көтерген жас отбасының ендігі бар тірлігінің үнемі осындай бір айналма тұйық аяда өтетінін символдайтылыы есепке көп алынбайды. Сүйектен, тастан, қарапайым металдан, кейін келе күміс пен алтыннан жай шығыршық түрінде соғылған жүзік атаулының қай дәуірде де тек жұбайлық өмірдің шеңбер-шегінен әлдеқалай қия басып, аттап шығуға қатаң тию есепті символдық қыззмет атқарған. Шынында да символ - адам баласын өзге тіршілік иелерінен айрықшалап тұратын нәрсе. Символдар әлемінің пайда болуы салт-жоралармен байланысты. Салт-жоралар символдар түрінде қызмет атқарған және оларды білу тұлғаның әлеуметтік орны мен мәдениетті білу деңгейін анықтаған. Соған байланысты, символдар өз-өзімен пайда болып өмір сүретін құбылыс емес, адам санасының жемісі болып табылады. Ғалым қазіргі заман 
жастарының да үйленген күннен бастап қолдарына жүзік салатыны бұдан төрт-бес мың жыл бұрынғы сол шумерлерден жалғасып келе жатқан дүниедегі ең бір көне салттың жаңғырығы деп біледі. Бірақ жүзіктің бұл туа қызметі, таңбалық статусы кейін жүре келе ұмытылғанға ұқсайды. Өйткені ол бүгінде тек сәндік үшін әшекей ретінде ғана тұтынылады. Қарастырылып отырған бұл жүзік сөзінің түрік тілдерінде қалыптасқан идиоэтникалық семантикасы жалпы алғанда осындай. Ал оның этимологиялық түбірі төңірегінде жалпы жүз формасының таза лингвистикалық табиғатына да барған ғалым, бұл этимонды «буын» ұғымымен байланыстырады. Жүзік шынында «буындық», «буынға тиесілі», «буынға салынатын» деген тәрізді мағына білдіретін сынды. «Мына бір дерек те соған айғақ: «Бууунлукъ украшение, надеваемое на запятстье, браслет - от бууун сустав руки, переходящий в пятерню». Себебі алдыңғының да, кейінгінің де семантикалық құрылымының негізінде сол «буын» ұғымы жатыр. «Идиоэтникалық аталмыш жүзік бірлігінің жүз түбірі және тіліміздегі кіші жүз, орта жүз, ұль жүз тіркестерінің жетек жүз сыңары да солай генетикалық жақтан бір сөзге келіңкірейді. Келіңкірейтіні екеуі де, алдыңғы да, артқы да бүтіннің жеке сегменттерінің, «буын» ұғымының тілдік көрінісі болып табылады. С.Аманжоловтың этноним сипатындағы бұл кіші жүз, орта жүз, ұльл жүз тіркестерінің жүз бөлігі бұтақ, бөлік дегенді білдіреді дегенін, әрі қарай жүзік сөзі жүз этимонымен ұлы (орта, кіші) жүз дегендегі жүз сыңары екеуінің идиоэтникалық семантикасының соншалықты дәлме-дәл сәйкес, абсолютті бірдей деп санайтынына ден қоя отырып, келтіреді. Ендеше кейінгі тіркес құрамындағы жүз есімі де сол алдыңғы жүзік жасалымының жүз этимоны сияқты «буын (звено)» мағынасында сипатталуға тиістілігі анықталады. «Біздің ойымызша, «буын» мағынасындағы көне түркілік йүз тува, хакас, карачай тілдерінде ғана емес, солармен қоса қазақ тілінде де кіші жүз, орта жүз, ұлы жүз тіркестерінің құрамында сақталған. Осылардағы жүз де, жүзік дегендегі жүз екеуі де, айналып келгенде, бір сөз. Бар айырмасы оның бірде морфологиялық (яғни туынды сөз құрамында түбір зат есім) енді бір жағдайда синтаксистік (яғни сөз тіркесінің жетек компоненті) қызметінде қолданылатыны. Бірақ бұл екі жағдайда да оның аталмыш «буын» мағынасы өзгермейді». Бұл - тұжырым. Сөздің семантикасына, тарихи фонетикасына қарай ғалым жасаған тұжырым. Аталған тілдік бірліктерден өзге ғалым шекпен, ішік, самалық, селебе, көйлек т.б. көптеген атаулардың семантикалық дамуын сан тілден, сан дереккөзден тынымсыз ізденіспен жинастырған деректерді сабақтастыра талдаған. Сол үшін ғалым аса күрделі, терең еңбектерді, атап айтқанда, Левитская Л.С., Малов С.Е., Манжигеев И., Маргулан А.Х., Менгес К.Г., Наджип А., Номинханов Ц-Д., Поппе Н.Н., Потебня А.А., Рамстедт М.И., Рясянен М., Севортян Э.В., Цинциус В.И., Юнусалиев Б.М., Янушкевич А, Gabain А. және қазақ ғалымдарының ғылыми еңбектерімен көз майын тауыса танысқан. Міне, қазақ тілі мен мәдениетін өмір бойы аспандата қадірлеп, М.Әуезовтей академик-жазушының шығармаларының этнолингивстикалық сипатын жеріне жеткізе түсіндірген біртуар ғалым филология ғылымдарының докторы Ербол Жанпейісов монографиясының азғана бөлігінің өзі салмақты түрде саралап оқуды, жүгірте емес, ойлана оқуды керек ететін мәнді де терең еңбектерді қазақ ғалымдары да жаза алатынын дәлелдейтін еңбек деу керек.

Еңбек - күрделі, түсінуі де санаға салмақ беретін, бірақ танымдық, тарихисемантикалық тұрғыдан бай дереккөз қоры бар және этнолингвистика мен тіл 
тарихына тереңдеуге мүмкіндік тудыратын ерекше еңбек. Бүгінде арамызда жоқ Ербол ағамыздың еңбегіне құрметпен қарайтынымызды білдіру мақсатында жазылған осы мақаланың соңында ғалым еңбектерінің жастар үшін, филологтар мен этнографтар үшін, когнитивтік лингвистика мен концептуалды зерттеулер жүргізіп, ғылымның қиындығынан ләззат алғысы келетіндер үшін әрі бағдар, әрі үлгі, әрі тіл әлемінің ерекшелігін танытатын нағыз ізденіс жемісі екенін қайталап айту ғана.

$* * *$

Қазақ тілінің тарихы мен қазақ этнолингвистикасының жанданып, ілгерілеуі жолында еңбек етіп жүрген енді бір ғалым - профессор Жамал Манкеева.

Талмай еңбектену бір нәтижеге әкелетіні әмбеге аян. Ж.Манкееваның әу деп бастаған ғылыми қадамы саналатын кандидаттық диссертациясындағы («Реконструкция первичных корней глагольных основ казахского языка» (Алматы, «Ғылым», 1991) этимологиялық талдаулары сарабдал шыққан. Жас та болса ғылымда сарыгідірлік таныта алған [2]. Осы жұмысқа байланысты айта кететін мәселе екі буынды етістік түбірлердің құрамындағы бір буынды өлі түбірлердің тізімін бере отырып, олардың ішінен этимология жасауға мүмкіндік жоқ 70 түбірді, атап айтқанда: бал-а (теңеу), бөл-е (баланы құндақтау), жаса (істеу және өмір сүру деген екі магынасында), төле, тие, шене (сөзбен түйреу магынасында), шұба, шыда, сопай, жуат, мұқат, мезге, нұсқ̧а, самга, мыжыь (көп сөйлеу магынасында), ренжі, тірке, марқай, мәңъгі, мөңүкі, саңъвы, мүңкі, дары (емі дару), жуы, жібі, кейі, қажы, кқасы (қолмен тырналау мавынасында), мойы, мүжі, нальы, шұқы, сасы, кіжін, жапыр, кідір, мүдір, шұбыр, т.б. бөліп көрсетеді. Алдыңғы жиған білімін кеңінен пайдалана отырып, қазақ тіліндегі мәдени лексиканың сырын докторлық диссертациясында ашты, мәдени лексикаға жататын сөздерді жинап-теріп, саралады, еңбегі жан-жақтылығымен, тілдік фактілерінің молдығымен айрықша болып шықты. Мәдени лексика туралы мәліметтер Ж.Манкееваның «Қазақ тіліндегі этномәдени атаулардың танымдық негіздері» еңбегінде талданды [3]. «Адам психологиясының, оның когнитивтік процесінің дамуын, жеке басының көріністерінің қалыптасуын ең алдымен, табиғатпен қарым-қатынасы, шаруашылық кәсібі арқылы өзектеген Ж.Манкеева тілдік құралдардың да ұлттық мәдени генезисін этнопсихология мен биосфера заңдылықтарынан өрбіте зерттеген. Зерттеуде ғалым «халықтың көкірегі», «халықтың жады», «ұлттық сезім», «рухани дүние», «халықтық психология» секілді ұғымдардың кездесуі содан, ғалым олардың маңыздылығына тоқталады.

Қазақ қарым-қатынасында сый көрсету, құрметтеу адамның малының санына қарай көрсетілетіні рас. Бірақ өзге де материалдық құндылықтардың рөлін кемсітуге болмайды. Өйткені материалдық құндылықтарадамзаттыңұлттық, тіптіконтитенттік ерекшеліктерін де қалыптастырады. Ал «тұрмыстық лексика элементтері диахронды зерттеулер жүргізгенде тарихи-этнографиялық тұрғыдан бастау-көз болса, екінші жағынан, лингвистикалық негіз қызметін атқарады», осы пікір материалдық лексиканың әр түріне арнаған талдауларында желі тартқан. Айталық, мата түрлері, оның ішінде жібек мата туралы ғалымдардың ой-толғамдарында жетіле түседі. Мысалы, жібек мата әрқашанда әсіре байлық пен асыл заттар санатында болғаны белгілі. Жалпы Еуразия континентіндегі халықтардың мемлекетаралық саяси, сауда байланыстарының орнауында және дамуында жібек ерекше орын алады. Жібек ерте ортағасырдан бастап, Шығыс және Батыс өркениеттерінің арасындағы алыс- 
берістің, сауда-саттық байланыстардың бірден-бір тауарлық эквиваленті болып келді, яғни ақшаның рөлін атқарды. Пікір жалаң болмас үшін Қазан төңкерісі алдындағы Хорезмдегі хан сарайын жазушының сипаттауына көңіл бөлуге болады. Сарай бишілерінің, кәнизактарының киімі де жібектен, асыл маталардан тігіл-ген: «Үстінде бахшылар мен бардтарды, мүбашақ пен газелдерді тыңдап, оған қасидалар мен желдірмелер ұласып, қаралай бой балқытар Хотан, Қашқар, Долан, Түрікмен мұқамдарына бейілдене балқып отырған шақта ішке көктен түскендей боп ак, қыззыл, көк, құара жібек пен шылтыра алтын көйлекке малынған, аяқтарына қоңьырауль күміс сақина салван он екі кәнизак кіріп келіп, дутар мен сыбызғы әуеніне қосылып, заузаның гүлінен қуана нәр алған көбелектерше шырқ айналып, мың бұралып билей жөнелді» (Есләмғалиұлы М.Әйтеке би, 116-б.). Бұл ғылыми факт емес, бірақ Хорезм сарайындағы киім үлгісін жазушының сипаттауы. Қазақ даласында да жібек қымбат мата ретінде бағаланды. Қазақ жерінде тараған жібек матаның газ, крепдешин, крепжсожет т.б. түрлеріне қазақы орта түрліше атаулар берді: баршын, барқыт, батсайы, қатипа, қылрмызы, тапта, торвын, торқ̧а, шәйі, атлас, кінауыз т.б. Тарихи деректер бойынша XIX ғасырдың ортасына дейін қазақы ортада киім тігуге көбінесе, aдpac, naйbl, биқасап, шәйі сияқты Орта Азиялық және Қытай маталарын пайдаланса, XIX ғ. II жартысынан бастап тұрмысқа сәтен, пүліш, сәрпенке, сиса сияқты Еуропалық және Ресейлік маталар көптеп ене бастаған. Мата түрлерінің өзі-ақ қоғам өзгерісін көрсетеді және тілде көрініс табады. Ж.Манкеева осындай сәттерді нақ аңғарып, тілдік материалдар қорынан таныс та бейтаныс мата атауларын келтіреді, мысалы, адрас, бүлде, баршын, батсайыл, биқасап (бекасап), боз, бөз, борлат, дабы, дүрия, жібек, құмқа, құатипа, қойқын, құлпы, қ̧ыжым, қырмыззы, ләмбек, ләйлі, манат, насар, пайы, парша, сәлдебоз, сиса, сыңсылма, сұрып, торқа, торвын, үлде, ұштап» т.б.

Жарқыратып таза, асыл матадан дұрыс киім кию кез келгеннің қолынан келмеген, анығында оған көптің қолы жетпеген. Айталық күміс кісе таву, таза былzарыдан етік кию, құндыз бөрік кию-кедейліктің емес, барлықтың, қолы жеткендіктің белгісі. Жақсы ат міну, жақсы киім кию, жақсының жанында жүру - ерекше әлеуметтік жағдайы барларға тән ишара. Адамдардың әлеуметтік жағдайы, жай-күйінің өзгелерден озықтығы я нашарлығы киім киісінен көрініп тұрған. Тіпті киімдер руы, жүзі жайлы хабардар жеткізгендіктен, қазақ қарым-қатынасында бәрі де ескерілген. Мысалы, бөрік, тыммақ түрлері ру-тайпалық ерекшелігіне қарай бөлінгенін, киімкешек үлгілерінде ру-тайпалық сәндер болғанын ғалым Ж.Манкеева былайша атап өтеді: «Керей тылмақ, найман тылмақ, арвын тыммақ, албан бөрік, қызай ққалnақ т.б.». Бұдан басқа тымақ түрлерін белгілі ғалым Е.Жанпейісов «Абай жолының» материалдарына сүйеніп көрсеткен еді: «Жекей тымақ, қаракесек тымақ, сегіз сай уақ тылмавы, сырмаланван алты сай найман тылмақ, төрт сай аласа төбелі тобықты тылмавы, жіңішке ұзын төбелі керей тылмавы т.б.». Бұл фактілер, өзге қазақ жазушыларының шығармаларында дәйектеле түседі: Кеше көргендей көз алдымда, басында құндыз бөрік, аяәында жарма қоныш көк етік, кісесі жарқырап андасанда көзімізге түскенде, ақыл тоқтата бастаған біздер: «о, шіркін, осы Абзал ағадай болсақ-ау!» - деп армандаушы едік (Сейдімбеков А.Аққыз, 36-б.). Артефакт ретінде бөрік өз иесінің әлеуметтік жағдайынан, ортасынан, қоғамдағы орнынан мейлінше жеткілікті хабар берген. «Досы - басқа, дұшпаны аяққа қарайтын» қазақ үшін бөріктің тігілу үлгісінің айрықша болуы да өзінше мәртебе саналған. «Сондықтан 
киім атаулары сонымен бірге әр тап өкілдері өздерінің әлеуметтік орнына, қызметкәсібіне қарай түрліше киінетінінен хабар береді», - дейді ғалым Ж.Манкеева. Расында да киімнің ақпараттық қызметінің күштілігін жазушылар жақсы көрсетеді: Сол Байшуақтың биік төбе сусар бөрік, биік өкие қоңыр саптама, қос бойы көк оюлы жжырым балақ қызыл қоңыр шалбар мен күдері шапанын киген соң Барат ел жақсыларынан айырмасы болмай қалған (Сегізбайұлы К. Беласқан, 155-б.). Мұндағы жырым балақ шалбар - балағының сырты жырылған, кең етіп тігілген ер адам шалбары. Ол атқа мініп-түсуге, сондай-ақ малдас құрып отыруға қолайлы болып келеді. Балағының жырым болуы да осындай ыңғайлы болуы үшін жасалған. Шалбардың пүліштен, шыттан сәнделіп тігілген түрлерін көбінесе жастар, салсерілер киген. Мұндай шалбарлар «сәнді болуы үшін балағындағы жырымын айналдыра түрлі жіптермен кестелеп, тіптен ышқырына шашақты бау да өткізген». Жырық балақ шалбардың жұмсақ етіп иленген теріден тігілген түрі Қытайдағы Бейжің орталық ұлттар университетінің музейіне қойылған. Шалбардың осы түрінің ғалым Ж.Манкеева «ешкі немесе киік терісінен тігілген тықыр жарғақ шалбар» болғанын келтіре отырып, оны қыста киетін ерлердің шалбарлары қатарында атайды. Ал келтірілген мысалдағы күдері шапан туралы мәлімет Ж.Манкеева келтірген қыстық киімдер ішінен де (ішік, жарғақ, күпі, шидем шекпен т.б.), жазғы сырт киімдер (жейде, жеңіл шапан, жалбағай т.б.) арасынан да, ұшыраспайды. Бірақ күдері белбеу «жұмсақ иленген бұлан не бұғы терісінен жасалған белдік» екені зерттеулерде айтылған. Былгары саптама (ол киіз байпақпен киілетін қонышты етік) Ж.Манкеева еңбегінде келтіріледі де, оны «қазақ еркектерінің қыста киетін аяқ киімдерінің» түрлері ішінде аталады. Ал көркем шығармадағы биік өкше қоңыр саптама сән-салтанатқа киілетін біркиер етік деп көрсетілген және оның ішінен киетін киіз байпағы туралы деректер көп ашыла бермейді. Сондықтан бұл етік туралы мәліметтерді хрономикалық, артефактілік дәлдік үшін анықтай түсу керек. Сондай-ақ алдыңғы мысалдарда келтірілген жсарма қоныш көк етік муралы мәліметтер де жоққа тән. Бірақ шоңқайма етік, саптама, қайқы тұмсық жұмсақ етік туралы аталған ғалым еңбектерінде мәліметтер бар. Бір-екі ғана киім түріне байланысты жинақталған мәліметтерден шығатын қорытынды мынадай: а) киім, киім түрлері туралы мәліметтерді жазушылар толық пайдаланбайды, әр жазушы оларға хрономика мен артефактілік құндылық ретінде емес, кейіпкер образын толықтырушы штрих ретінде ғана қарайды; ә) әр аймақтың киім киісіндегі, жасалу үлгісіндегі ерекшеліктерді әлі де болса тереңірек зерттей түсу керек, деректерді толықтыру керек. Ол фактілер не үшін керек? Мұндай фактілердің барлық шарттарға сай дұрыс болып, қолданыс табуы тек коммуникациялық тұрғыдан ғана емес, когнитивтік-танымдық тұрғыдан және мәдениаралық коммуникация тұрғысынан да құнды, маңызды.

Сал-серілер туралы, олардың киім үлгілері туралы сөз қозғай келе: «Бір ғана сал-серілердің киімінің өзі ғажайып өнер туындысы саналған. Оларда жарқындылық, романтикалық рең басым болады. Мысалы, олардың шалбары да ерекшеленіп, өз сипатына сәйкес сал шалбар деп аталған», - дейді Ж.Манкеева. Киім адам туралы жақсы да, нашар да пікір қалыптастырады. Яғни артефакті ретінде киім коммуникацияда, қарым-қатынас кезінде ерекше рөл атқарады. Киім-кешекке байланысты Ж.Манкеева мынадай қорытындыға келеді: «Қазақтың киім атаулары- 
ның алуан түрлі топтары мен байлығы хандар мен сал-серілерді былай қойғанда, халықтың өзінің де өте сәнді киінгенін көрсетеді. Бүгінде сол киімдердің жарқын үлгісінің бірсыпырасы тарих тереңінен еміс-еміс жеткен» [3].

Этномәдени лексика элементтері диалектілік сөздіктердің негізгі құрамдас бөлігі, өйткені әр аймақтың шаруашылық жүргізуіне қарай, игерген кәсібіне сай, жердің ерекшелігіне, климатқа байланысты тұрмысына қажетті сөздердің тобы болса, ол сөздерді басқа бір аймақтың тұрғындары қолданбауы әбден мүмкін, сондықтан мұндай сөздердің таралу аймағы шектеулі келеді. Ал кейбір тұрмыстық сөздер жалпы халыққа ортақ сөздер болады да, олардың мағынасы түсінікті келеді, мұндай сөздерді барлық диалектілік аймақтардың тұрғындары пайдалануы ықтимал. Міне, Ж.Манкеева осы мәселені жан-жақты түсіне келіп, жұмысында, өзі атап көрсеткендей, «зерттеу нысанына іліккен негізінен ұлттық бояуы қою, халықтық лексика. Атап айтқанда, тұрмыста қолданылатын зат, бұйым, еңбек құралдары, үй жиһаздары, киім т.б. атаулары, дәстүрлі кәсіпке қатысты терминдер» болып табылады деп көрсетеді. Мысалдарды әр түрлі қайнаркөздерден, атап айтқанда, тарихи тақырыпқа жазылған көркем шежірелерден, ақын-жыраулар тілінен, XVIII-XIX ғғ. ақындардан, фольклордан, диалектілік ерекшеліктерден, фразеологизмдерден жинастырды. Оларды он бөліктен тұратын лексика-семантикалық топқа бөлген. Соның нәтижесінде, зергерлік әшекейлердің басқа, сырт киімге тағылатын түрлері туралы этнографиялық мәліметтермен бірге олардың шығу тегі жөнінде терен тілдік мәліметтер жинақталып, зергерлік құрал-саймандардың түрлері жөнінде фактілер топтастырылған. Одан өзге киім-кешек атаулары, қолөнер туындылары, еңбек құралдары мен ыдыс-аяқ атаулары, киіз үй құралдарының атаулары, қазақтың музыкалық аспаптары мен қару-жарақ атаулары, ұлттық тағам атаулары топтастырылған, тілдік, танымдық, ділдік талдаулар жинақталған кешенді еңбек дүниеге келген. Еңбекте атаулардың символикалық, бейнелік мағыналары және этимологиялық талдаулар арқылы көптеген сөздердің этнолингвистикалық табиғаты анықталған.

Міне, заманы бір, ізденістері бір бағыттағы екі белді ғалымның қазақ этнолингвистикасын ілгерілеткен еңбектері туралы осындай ойдамыз.

Мақала «Мдңұсілік ел - выльими негізде» атты выллымды дамытудың басым багытынының «Қазақ тілі кеңзістігіндегі ұлттыьқ-мәдени код: символдың архетиптік мәртебесін және тұлваның тарихи-мәдени типін анықтаудавы қызиметі» (ЖТН АРО5131406) жобасы бойынша жарық көріп отыр.

\section{ӘДЕБИЕТТЕР ТІЗІМІ:}

[1] Жанпейісов Е. Қазақ ескіліктері. - Алматы: «Қазақ тілі» баспасы, 2018. - 352 б.

[2] Манкеева Ж.А. Реконструкция первичных корней глагольных основ казахского языка. - Алма-Ата, 1991. - С. 154.

[3] Манкеева Ж. Қазақ тіліндегі этномәдени атаулардың танымдық негіздері. Алматы: Жібек жолы, 2008. - 356 б. 